\title{
Relationship between Teachers' Job Satisfaction and Their Attitudes towards Students' Beliefs and Motivation
}

\author{
Hadi Salehi ${ }^{1}$, Elham Taghavi ${ }^{1} \&$ Melor Md Yunus ${ }^{2}$ \\ ${ }^{1}$ English Department, Faculty of Humanities, Najafabad Branch, Islamic Azad University, Najafabad, Isfahan, \\ Iran \\ ${ }^{2}$ Faculty of Education, Universiti Kebangsaan Malaysia, Bangi, Malaysia \\ Correspondence: Hadi Salehi, English Department, Faculty of Humanities, Najafabad Branch, Islamic Azad \\ University, Najafabad, Isfahan, Iran. E-mail: hadisalehi1358@yahoo.com
}

Received: March 2, 2015 Accepted: April 3, 2015 Online Published: June 29, 2015

doi:10.5539/elt.v8n7p46 URL: http://dx.doi.org/10.5539/elt.v8n7p46

\begin{abstract}
Many studies have been done in the developed countries due to the importance of job satisfaction; however, only a limited number of studies have been conducted on teachers' job satisfaction in Iran. This study is an attempt to investigate the relationship between teachers' job satisfaction and their attitudes towards students' beliefs and motivation.To this end, both qualitative and quantitative research methods including interview protocols and questionnaire were utilized. To collect data, in the quantitative part of the study, a validated questionnaire was administered to sample of 340 among the English teachers, teaching in Iranian language institutes in Isfahan. After gathering the questionnaires, those teachers willing to be interviewed were selected for in-depth interview. Both quantitative and qualitative data were categorized, coded and analyzed based upon the main themes and the respective research questions. The results revealed that there are empirically positive significant relationships $(\mathrm{t}>2.56, \mathrm{P}<0.001)$ between teachers' job satisfaction and their attitudes toward students' motivation and beliefs. Moreover, the interviews showed that teachers' level ofjob satisfaction was high, although they are not satisfied with financial matters. The finding can shed more light on the area of teachers' job satisfaction and related factors to have better understanding of the relationship between job satisfaction and job performance. Furthermore, educational institutions through considering the results of the study can improve teachers' perceptions of their job and improve job environment to manage language learning institutes or schools better than before.
\end{abstract}

Keywords: attitudes, beliefs, motivation, teachers' attitudes toward learners, teachers' job satisfaction

\section{Introduction}

In recent years, more and more people around the world are in need of acquiring a higher level of competence in the learning English as a second or foreign language, making the English language teaching profession one of the popular careers. According to Kozloski (2002) although extrinsic rewards such as payment or positive teacher evaluation was involved and supportive, it was the intrinsic motivation that played more important role and was responsible for teachers' motivation. Although a growing interest in teacher job satisfaction in the field of EFL/ESL developed quickly during the last two decades, assessing levels of job satisfaction among teachers has increased because of growing trend of qualified teachers leaving the teaching profession for reasons other than retirement (Ingersoll, 2003). If foreign language teachers can be supported, in some ways, to understand where they stand, and if they can stand there with dignity, security, satisfaction, then all schools students and communities, can benefit and meet targets of policy planning (Papastamatis, 2009). Therefore, the goal of this study is to extent our knowledge about teachers' job satisfaction and their attitudes towards their learner through investigating the teachers' perceptions of their overall job satisfaction and exploring the way teachers see their students' beliefs and motivation to learn English as second language.

\section{Literature Review}

Some studies indicated that job satisfaction is connected with teachers' sense of efficacy (Currall, Towler, Judge, $\&$ Kohn, 2005). Therefore, when teachers have high perception of their professional job quality, they also have positive attitudes towards teaching, as an achievement factor. As Drake (2002) assumed, teachers' skills and 
effectiveness are likely to be changed over time so that providing more professional development opportunities to increase teachers' skills and self-efficacy can be helpful to reduce the level of job stress and as a result increase satisfaction from teaching.

Cranny, Smith, and Stone tried to find out the various ways that job satisfaction was define in 1992. Their analysis, finally, help the researchers define job satisfaction as "an affective (that is, emotional) reaction to one's job, resulting from the incumbent's comparison of actual outcomes with those that are desired (expected, deserved, and so on)" (p. 1). One of the most significant in the issue was the Hawthorne studies, leading up to the promotion of job satisfaction (Roethlisberger \& Dickson, 1939). The goal of these studies, conducting at Harvard Business School from 1924 to 1933, was to find out how different conditions such as illumination can affect the workers' productivity. The result of the studies showed that changes in conditions and work context temporarily lead in increasing workers' productivity.

Hong Goo (2011) pointed out that job satisfaction is also worth consideration from a humanitarian perspective. In other words, it has a great impact on employees' health. Satisfied workers are likely to live for longer time and are healthier (Faragher, Cooper, \& Cass, 2002; Fisher \& Sousa-Poza, 2009). An important finding for organizations to note is that job satisfaction has a rather tenuous correlation to productivity on the job. In line with Hong Goo (2011), although the accessible research has not consistently shown a relationship between job satisfaction and job performance, several studies (Bowling, 2007; Judge, Thoresen, Bono, \& Patton, 2001) recommended that there is a positive relationship between overall job satisfaction and job performance. Such results are fundamental for researchers and businesses, as the idea that satisfaction and job performance are directly linked to one another is often cited in the media and in some non-academic management text.

Contrary to many studies done, Hackman and Oldham (1980), Maslow (1954), and Herzberg et al. (1959) are pioneering studies that provoke more studies in the field. Teachers' job satisfaction questionnaire (TJSQ) using to measure job satisfaction was developed from studies done by Maslow and Herzberg in 1954. TJSQ is, in fact, taxonomy to introduce the involving factors. According to Hackman and Oldham' studies in 1980, if job characteristics of task identify, task significance, skill variety, autonomy and feedback increased, feedback results will be in a more positive psychological state. The employees' organizations are the beneficiary of having a positive influence on work outcome such as increasing the level of job satisfaction, motivation and work effectiveness. Based on Hackman and Oldham'sresults if teachers find their work meaningful or beware of results of work, their work efficiency would increase.

Teaching professions similar to other jobs is authorized by the intentional attempt made by teachers (Townsend $\&$ Bates, 2007). As there can be a strong relationship between teachers' perception of English language as a job, they make endeavourer to improve not only their standards but also the quality of the job. So researchers tend to feel concern about the situation (Johnston, 1997). According to Caprara (2003) job satisfaction is "decisive element" that has strong effects on teachers' attitudes and even performance (p. 823). Similarly job satisfaction is very significant fact resulted from self-efficacy.

Attention to the students and teachers' beliefs has been always an important educational inquiry and a focus of educational research. For example, Kern (1995) discussed the significance of belief about language learning through comparing learners' belief at different institution and with those of their teachers. Investigating change in students' beliefs in relation to those of their teachers was another matter of his interest; in order to develop hypotheses about the potential influence of teachers' beliefs on students' beliefs. According to him, results were found to be significantly affected by the type of analysis: global analyses of group and analyses of individuals and course section groups.

In the regard of learners and teachers' motivation, Bernaus and Wilson (2008) investigated the relationship between student motivation and achievement in English and its relation to their teacher motivation and strategy use in the classroom. Research participants were 31 teachers in Catalonia (Spain) and the 694 students in their classes. The results of the study suggested that teachers' motivation is related to their use of motivating strategies, which are related to student motivation and English achievement. Thus, any changes in the educational system that promotes higher levels of teacher motivation should result in improved levels of education of the students (Bernaus \& Wilson, 2008).

According to teachers, they are satisfied when working with students, or seeing students' continual accomplishments (Cockburn \& Haydn, 2004). Evans and Ingersoll (2001) assumed that there is a connection between leaving the profession and feeling dissatisfied. Moreover, Liu and Ramsey (2008) mentioned that one of the greatest factors affecting teachers' job satisfaction is stress, which is the consequence of poor work condition as well as the amount of time for planning preparing materials to teach. That is inadequate time and heavy 
teaching leads to reduce the level of job satisfaction. Considering the key role of teachers in deciding on standards at schools and providing children with necessities through which they can be successful. We need to know more about the most important methods that teachers use to assist their learners' academic goals.

In the regard of teacher-student relationships Veldman (2005) studied a development of teacher-student relationships and teachers' job satisfaction throughout the careers of four veteran teachers who retained high job satisfaction. Teachers' job satisfaction appeared positively related to the self-reported quality of the teacher-student relationships. Positive retrospective teacher perceptions did not always coincide with positive student perceptions. The researchers found that teachers might have positive job satisfaction despite, in the eyes of the students, a poor teacher-student relationship. In Iran like other countries, many studies considering the importance of Iranian learners' beliefs and motivation and their behavior (Papi \& Abollahzadeh, 2012), and teachers' job satisfaction (Nojani, Arjmandnia, Afrooz, \& Rajabi, 2012; Zainalipour, Sheikhi, \& Mirkamali, 2010) have been done. Still conducting researches regarding teachers' job satisfaction and its relation with other key factors such as students' beliefs and motivation is essential.

Considering the importance of the learners' and teachers' belief systems to our understanding of language learning/teaching as well as job satisfaction and productivity on the job, the study aims to find this possible relationship between teachers' job satisfaction and their attitudes towards students' beliefs and motivation. More precisely the study tried:

- To investigate the probable relationship between EFL teachers' job satisfaction, and their attitudes towards students' beliefs,

- To explore the probable relationship between EFL teachers' job satisfaction and their attitudes towards students' motivation,

- To examine the teachers' perceptions of their overall job satisfaction.

So the study seeks answers to the following questions:

1) Is there a significant relationship between teachers' job satisfaction and their attitudes towards students' beliefs about learning English?

2) Is there asignificantrelationship between teachers' job satisfaction and their attitudes towards students' motivation in learning English?

3) How do English teachers perceive the overall level of their job satisfaction?

\section{Method}

\subsection{Participants}

Participants of the study were English teachers who had their BA, MA, or PhD degree; teaching in Iranian language institutes in Isfahan. The participants were both female and male teachers (81female, 128male) who had various years of experience (from a year to 10years and above). They were selected from at least seven language institutes; as in the study, gender was not considered a determining factor in choosing the participants.

\subsection{Instruments}

In the study, both questionnaires and interviews were utilized to collect the required data. Questionnaire was used to gain quantitative data and interviews were used to help the researcher obtain the qualitative data needed for the study to expand the detail learned from the quantitative section.

\subsubsection{Teachers' Questionnaire}

The purpose of this questionnaire was to investigate the probable relationship between EFL teachers' job satisfaction, and their attitudes towards students' beliefs, and motivation. It consisted of two parts to provide the researcher with an overall teachers' job satisfaction and their students' beliefs and motivation for learning English as a foreign language. The teacher's questionnaire was developed in Englishand by the researchers. It was piloted on 60 English teachers and Cronbach's alpha coefficient was calculated. The Cronbach's alpha value for all the variables exceeded the minimum required value of 0.7 and hence, the scale of variables is highly reliable. 
Table 1 . The results of the reliability test

\begin{tabular}{llll}
\hline Variables & No. of items & Mean & Cronbach's Alpha \\
\hline Beliefs & 15 & 3.56 & 0.860 \\
Motivation & 15 & 3.57 & 0.889 \\
Job Satisfaction & 15 & 3.57 & 0.821 \\
\hline
\end{tabular}

As shown in Table 1, the Cronbach's alpha value for all the variables exceeded the minimum required value of 0.7 and hence, the scale of variables is highly reliable.

\subsubsection{Interview}

The second tool for gathering information was interview protocol. Interview, the qualitative portion in this study, is used to gain further or supplemental information that the quantitative method, that is questionnaire, cannot disclosed. While teachers' questionnaire gave a general understanding as to investigate the relationship between EFL teachers' job satisfaction and their attitudes towards students' beliefs and motivation, teachers' interviews provided information that is more detailed. The purpose of the interview questions was to probe more deeply Iranian English teachers' perceptions of their overall job satisfaction.

\subsection{Procedure}

Three hundred and fortyquestionnaires were distributed among the English teachers, teaching in different English language institutes in Isfahan. Since it was a part of the institutes' condition to allow the researchers collect data, the details of the institutes are kept anonymous in all reports generated from the data. After 20 days, 233 questionnaires were collected; however, 24 questionnaires were discarded from the analysis process due to the major data-missing problem and only 209 questionnaires were considered for data entry and data analysis procedures. All English teachers who had already participated in the survey were invited for the interview; however, only six males and three females were willing to be interviewed. All performed interviews were recorded and transcribed so that the risk of missing the interviewees' comments wasreduced. Finally, the transcribed interviews were organized, coded and analyzed.

\section{Results}

The data was tabulated and calculations were made through SPSS, version 19 and AMOS. The analysis of qualitative part of the study, which involved personal interviews with teachers, started after collecting the qualitative data because the collected information were fresh in the researcher's mind. The recordings were transcribed and the observation notes were rewritten as an opportunity for analysis.

\subsection{Data Analysis (Quantitative Part)}

The first part consisted of four items of teacher personal characteristics related to demographic information including gender, age, academic qualifications, and years of teaching experience. As shown in Table 2, the majority of the respondents were male constituting 61.2 percent of the samples.

Table 2. Respondents' gender profiles

\begin{tabular}{lll}
\hline Gender & Frequency & Percent \\
\hline Female & 81 & 38.8 \\
Male & 128 & 61.2 \\
\hline
\end{tabular}

Table 3 also illustrates the participants' educational level. As shown, most of the respondents had graduated masters degree $(\mathrm{N}=115,55 \%)$, followed by bachelors' degree holders $(\mathrm{N}=66,31.6 \%)$ and only 13.4 percent had $\mathrm{PhD}$. 
Table 3. Respondents' education level

\begin{tabular}{lll}
\hline Education & Frequency & Percent \\
\hline Bachelors & 66 & 31.6 \\
Masters & 115 & 55.00 \\
PhD & 28 & 13.4 \\
\hline
\end{tabular}

According to Table 4, most of the participants had 1-3 years of work experience ( $\mathrm{N}=178,85.2 \%)$, followed by those having 7-9 years of experience in teaching English $(\mathrm{N}=14,6.7 \%)$. The least number of teaching experience were those who had more than 10 years of experience $(\mathrm{N}=4,1.9 \%)$.

Table 4. Respondents' years of work experience

\begin{tabular}{lll}
\hline Experience & Frequency & Percent \\
\hline 1-3 years & 178 & 85.2 \\
4-6 years & 13 & 6.2 \\
7-9 years & 14 & 6.7 \\
10 years and above & 4 & 1.9 \\
\hline
\end{tabular}

As shown in Table 5, most of the respondents had university education in English major $(\mathrm{N}=69,58.5 \%)$.

Table 5. Respondents' major

\begin{tabular}{llll}
\hline & Frequency & Percent & Mean \\
\hline English & 69 & 58.5 & \multirow{2}{*}{1.58} \\
Other Majors & 49 & 41.5 & \\
\hline
\end{tabular}

\subsubsection{Data Missing and Normality}

After the demographic analysis, data missing check was conducted to make sure that the data set is complete. Eighteen questionnaires were found to partially have missing data, each with 1-2 items. Since the missing data portion is below $10 \%$, replacement method was done and an average of the next and before question items was calculated and replaced in the missing data. This approach is consistent with Hair et al. (2010). Furthermore, items $34,37,40,44$ were designed in such a way to have reverse answers with other similar items. Before the analysis is started, respondents' answers for these questions were coded reversely, as outlined by Hair et al. (2010).

Table 6. Results of normality test

\begin{tabular}{llll}
\hline & Beliefs & Motivation & Job Satisfaction \\
\hline Skewness & -0.54 & -0.49 & -0.50 \\
Std. Error of Skewness & 0.22 & 0.22 & 0.22 \\
z-value & -2.44 & -2.21 & -2.26 \\
Kurtosis & 0.24 & 0.87 & 0.32 \\
Std. Error of Kurtosis & 0.44 & 0.44 & 0.44 \\
z-value & 0.54 & 1.97 & 0.73 \\
\hline
\end{tabular}

In the next step, the assumption of normal distribution was examined. Table 6 shows the results of the normal distribution test. As shown, the z-value results for the skweness and kurtosis are in the range of -2.56 and +2.56 , 
as outlined by Hair et al. (2010). This implies that the distribution is normal and there is no violation if normal distribution for this data set.

\subsubsection{Reliability and Validity Tests}

As mentioned, before the data is collected, the developed questionnaire was given to two academicians for their comments and opinions and the amendments were done based on their suggestions and comments. This ensures the content and face validity of the scale. After that, a reliability test was utilized, using Cronbach's alpha technique.

Table 7. The results of the reliability test

\begin{tabular}{llll}
\hline Variables & No. of items & Mean & Cronbach's Alpha \\
\hline Beliefs & 15 & 3.56 & 0.860 \\
Motivation & 15 & 3.57 & 0.889 \\
Job Satisfaction & 15 & 3.57 & 0.821 \\
\hline
\end{tabular}

As shown in Table 7, the Cronbach's alpha value for all the variables exceeded the minimum required value of 0.7 and hence, the scale of variables is highly reliable.

\subsubsection{Validation Procedure}

To examine the convergent and discriminant validity of the questionnaire, the confirmatory factor analysis (CFA) technique was applied and the parameters were estimated using the maximum likelihood estimation (MLE) technique using AMOS 5. Before testing the validity, the model goodness-of-fit was examined using different model fit indices proposed by Liu, Marchewka, $\mathrm{Lu}$, and $\mathrm{Yu}$ (2004). These measures are the ratio of Chi-square $(\chi 2)$ to degrees of freedom (d.f.), adjusted goodness of fit (AGFI), non-normalized fit index (NNFI), root mean square error of approximation (RMSEA), comparative fit index (CFI) and root mean square residual (RMSR). During this process, the items 7,11 to 19,28 to 33 , and 39- 45 were omitted due to low factor loading values (below 0.6). The results of measurement model fitness- after the omission of the items with low loadings- are summarized in Table 8.

Table 8. Fit indices for measurement model

\begin{tabular}{ll}
\hline Fit Indices & Result value \\
\hline$\chi^{2}$ & 401.21 \\
d.f. & 206 \\
$\mathrm{P}$ & 0.000 \\
$\chi^{2 / \text { d.f. }}$ & 1.948 \\
NNFI & 0.921 \\
CFI & 0.930 \\
RMSEA & 0.067 \\
RMSR & 0.051 \\
AGFI & 0.805 \\
\hline
\end{tabular}

As shown in Table 9, all the result values meet the recommended value. Having found a good model fit, the validity of the scale can be assessed. 
Table 9. The loadings of the items

\begin{tabular}{lll}
\hline Question Items & Corresponding variable & Loadings \\
\hline Q1 & Belief & 0.764 \\
Q2 & Belief & 0.68 \\
Q3 & Belief & 0.834 \\
Q4 & Belief & 0.809 \\
Q5 & Belief & 0.763 \\
Q6 & Belief & 0.797 \\
Q8 & Belief & 0.736 \\
Q9 & Belief & 0.763 \\
Q10 & Belief & 0.703 \\
Q20 & Motivation & 0.727 \\
Q21 & Motivation & 0.708 \\
Q22 & Motivation & 0.716 \\
Q23 & Motivation & 0.819 \\
Q24 & Motivation & 0.825 \\
Q25 & Motivation & 0.825 \\
Q26 & Motivation & 0.749 \\
Q27 & Motivation & 0.729 \\
Q34 & Satisfaction & 0.699 \\
Q35 & Satisfaction & 0.781 \\
Q36 & Satisfaction & 0.817 \\
Q37 & Satisfaction & 0.727 \\
Q38 & Satisfaction & 0.709 \\
\hline
\end{tabular}

As shown in Table 9, the loading values of items on their corresponding variables were found significant (t-values > 1.96). Furthermore, as illustrated in Table 10, composite reliability (CR) and average variance extracted (AVE) values for all the variables were found to be sufficiently high. Therefore, the convergent validity of the scale was ensured. As shown in Table 10, it was also found that the AVE values of each variable are higher than the square correlation values of the variables.

Table 10. The CR and AVE values

\begin{tabular}{llllll}
\hline \multirow{2}{*}{ Variables } & \multirow{2}{*}{ CR } & AVE & \multicolumn{3}{l}{ Square Correlations } \\
\cline { 5 - 6 } & & & Beliefs & Motivation & Satisfaction \\
\hline Beliefs & 0.92 & 0.58 & 1 & & \\
Motivation & 0.91 & 0.58 & 0.29 & 1 & 1 \\
Satisfaction & 0.80 & 0.51 & 0.13 & 0.11 & 1 \\
\hline
\end{tabular}

Considering the above results, it can be concluded that the scale has sufficient validity. The results of the confirmatory factor analysis have been shown in Figure 1. 


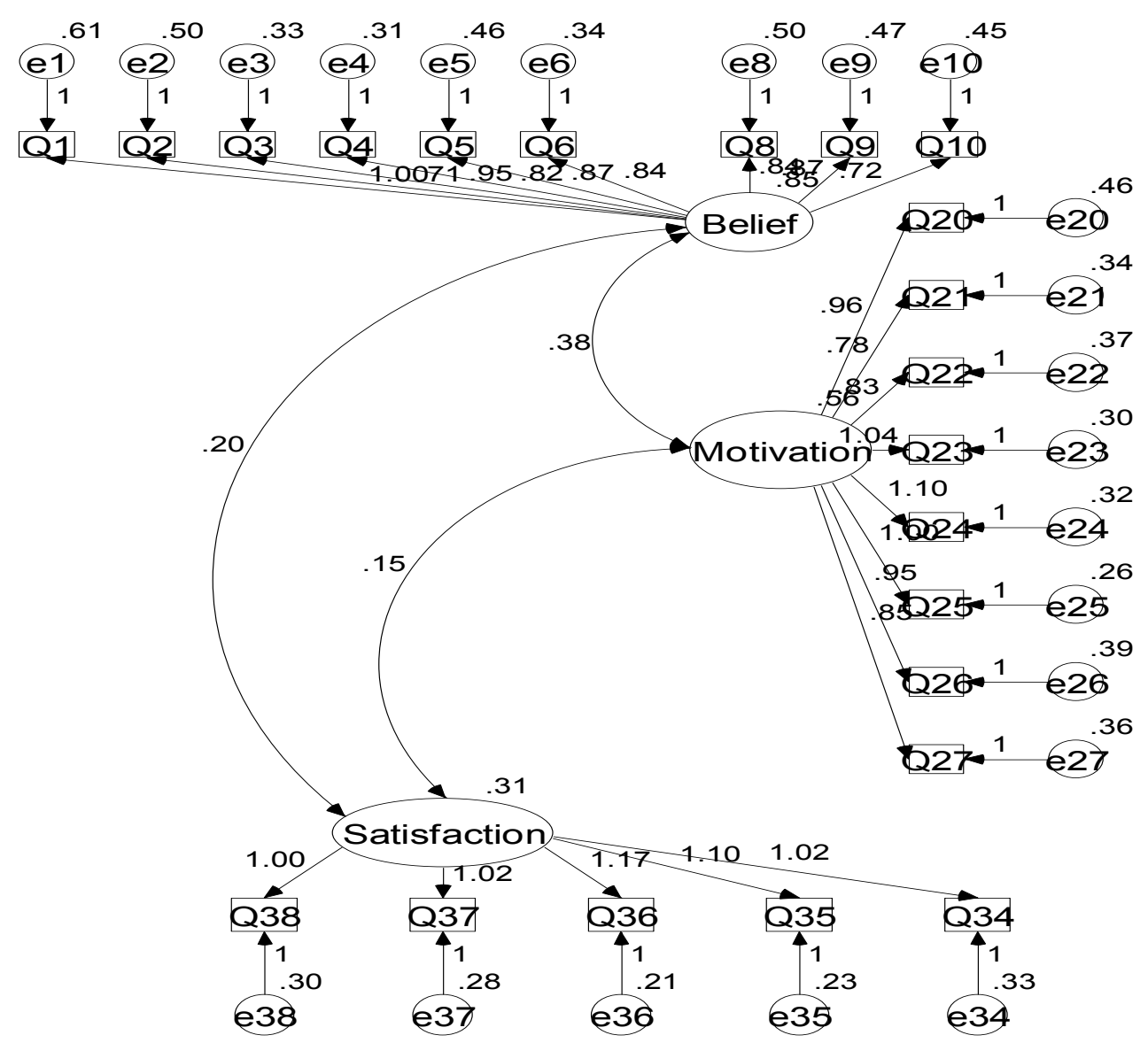

Figure 1. Results of the confirmatory factor analysis

\subsubsection{Testing the Hypotheses}

Since there are two dependent variables in the model and this research aimed to examine the impact of satisfaction on both dependent variables simultaneously, structural equation modeling (SEM) technique, using AMOS 5 was utilized. First, the goodness of fit for the structural model was tested and as shown in Table 11, the results meet the minimum required values. This indicates that the structural model has a good fit.

Table 11. Structural model fitness results

\begin{tabular}{ll}
\hline Fit Indices & Result value \\
\hline$\chi^{2}$ & 319.188 \\
d.f. & 199 \\
$\mathrm{P}$ & 0.000 \\
$\chi^{2 / \text { d.f. }}$ & 1.604 \\
NNFI & 0.950 \\
CFI & 0.957 \\
RMSEA & 0.054 \\
AGFI & 0.853 \\
\hline
\end{tabular}


The results of the SEM showed that there are empirically positive significant relationships $(t>2.56, \mathrm{P}<0.001)$ between teachers' job satisfaction and their students' motivation and beliefs. Therefore, both the hypotheses of this research rejected. The t-values and p-values of the relationships have been shown in Table 12. Moreover, the results of testing the hypotheses are shown in Figure 2.

Table 12. T-Values and P-Values

\begin{tabular}{llll}
\hline Dependent variables & Independent variable & t-values & P-values \\
\hline Belief & Satisfaction & 5.102 & 0.001 \\
Motivation & Satisfaction & 4.849 & 0.001 \\
\hline
\end{tabular}
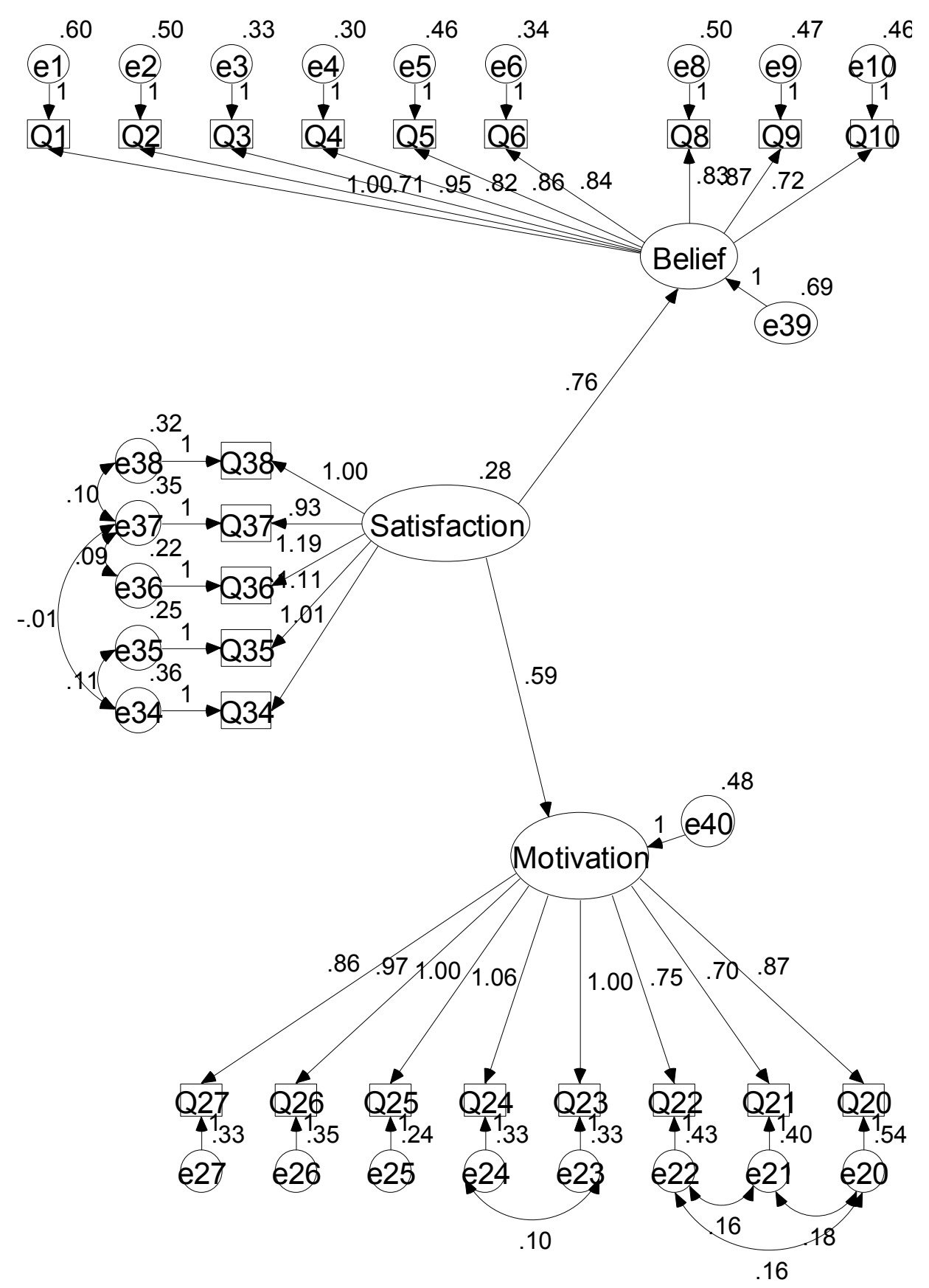

Figure 2. Results of the hypotheses 


\subsection{Interviews Results (Qualitative Part)}

This part reports the results obtained from the interviews with teachers teaching in language institutes in Isfahan. Teachers were supposed to answer was their overall level of satisfaction with their job as a teacher. Responses for the job satisfaction factor of responsibility, students' direction of motivation were almost similar and lengthy. The teachers felt very strongly on the questions and were quick to explain their thoughts and feelings. It is worth mentioning that all the information gathered in this part were presented in an unbiased and complete manner.

RQ3) How do teachersperceive the overall level of their job satisfaction?

As the required data for thisquestion were gathered only through interview, teachers were supposed to answer three questions when the interview was made. When the question on motivation to choose to be a teacher was posed, they all answered very similar. The most important reasons for them were their interest in teaching, learning English, their ability to teach, opportunity for getting familiar with new people from different parts of society, and having a job. For example, Maziar started to teach what he learnt from a native speaker and tried to put what he knew into practice. However, the first important reason he mentioned was that he loved teaching and he really enjoyed doing that. However, the only reason that Shohreh brought was that she was interested in teaching but not English, which little by little get interested in English. Or Nooshin who pretended to be a teacher in front of the mirror when she was a child. Kiyan even would like to transfer his enthusiasm for teaching to his students.

In answer to the question about the level of job satisfaction, putting their experience aside, the teachers claimed that the level of job satisfaction is high, although they are not satisfied with financial matters. Among all the interviewed teachers, only Shohreh and Mehrdad brought different factors up that in their opinion affect the level of job satisfaction which are payment and atmosphere in workplace. In line with Shohreh, Mehrdad talked about status in the society and students judgments. In line with students' judgments, he said that students judge according to their expectation; they do not know the methodology and he believed that thelanguage institutes support students because the institutes want to make money. Nevertheless, he was satisfied with his job because his co-workers in the language institute were important to him.

When they asked for discussing their perceptions of their colleagues'level of job satisfaction, interestingly all of them assumed that their colleges are not satisfied with job. Asking for giving percentage, they give a high percentage such as $70 \%$ of their colleagues. Maziar stated that while he is not sure about all of them, most of his colleagues are just trying to get along with it. Shoherh also mentioned that they have some raises in their payments each year although they are not satisfied. Generally, regarding job satisfaction the intervieweeswere not satisfied at all. However, on the subject of helping other people with their needs, making them happy, making them grow, the teachers were all satisfied.

\section{Discussion}

Consistent with claims supporting the assumption that teachers need encouragement and motivation as well as students to do their job properly, the results of this study showed that behavior of learners which derived from their beliefs (Fishbein \& Ajzen, 1975; Ajzen, 1988) can affectteachers motivation, just similar to feedback. Toshiko (2010) assumed that when teachers perceive their learners become skilled at what they are taught and feel satisfy with their [students] motivation level and growing in learning, they feel satisfied and motivated. The findings from this study further support Toshiko assumption. To be precise, teachers participated in the study defined a teacher a successful one if $\mathrm{s} / \mathrm{he}$ can motivate his or her students or have their appreciation. One of teachers, Maziar, explicitly said that if his learners are like nagging all the time or if they are not satisfied, he could get or feel the bad feedback. And it can greatly depress him and on the other hand if he understands student are learning well; therefore, they feel satisfied with class and with what they are doing in the class. It will affect the teacher a lot and $\mathrm{s} /$ he will have a lot of satisfaction.

Kennedy (1996) hypothesizes that teachers' beliefs can form the way teachers behave. As Brown and McGannon (1998) suggested, it is important to help trainees reflect on their beliefs because learners come to class and bring their beliefs to a teacher education program that influence on what and how they learn (Richardson, 1996). Accordingly, in response to the questions concerning learners' beliefs, the satisfied teachers assumed that most of their learners consider English important especially at higher levels, because they have plain goal to learn. Such beliefs help them to do their best to teach material in the best way and use methods that make the material as interesting as possible. In addition to beliefs, generally, teachers participated in the interviews enlightened that they think their learners are enough motivated; although, it depends on their both level and goals to learn English. They clarified that getting confused is not because learners think that English is difficult, but it is on account of lack of knowledge or some psychological problems like shyness. They referred to three types of knowledge that 
a teacher should acquire; knowledge about general English, teaching methods, and knowledge how to make learners happy. Such attitudes, popular among them, resulted in behaving and teaching in a way that is best in their opinion. The result is in proportion to McGannon (1998) and Breen (1991) findings. In their studies, they illustrated that teachers had many beliefs about how foreign language are learned and that influenced their teaching. Also, Kennedy's (1996) hypothesis that beliefs can form the way teachers behaves.

Many studies have shown that work itself, teaching and being a teacher, could play a role as a satisfier, also daily tasks could be classify as a factor that increases job satisfaction as an intrinsic motivator (Fried \& Ferris, 1986; Hackman \& Oldham, 1980; Herzberg, 1959). Corresponding to these studies, results of the study showed that the level of job satisfaction is high because the most important reason for teachers is their interest in teaching, English, and their ability to teach.

In addition, the only reason that made teachers feel dissatisfied was the payment. Similar to this result, Coşkuner (2001) conducted a study in which one hundred teachers from nine institutes participated and confirmed the hypothesis that low salaries were the most important reason that makes teachers think about leaving their job.

With regard to teacher and student relationships, Veldman (2005) studied teacher-student relationships and teachers' job satisfaction throughout the careers of four veteran teachers. Findings verified that teachers' job satisfaction is positively related to the self-reported quality of the teacher-student relationships. In the same way, the interviewed teachers claimed that they are friend with their students and all of them mentioned the importance of such a relationship and its impact on their learners' motivation and beliefs.

Moreover, according to the results of interviews, teachers tend to transfer not only their knowledge but also their enthusiasm of being teachers to their students which is close to Nguni, Sleegers, and Denessen's (2006) finding. As stated by Nguniet al. satisfied teachers show a lot of excitement and interest about giving more energy and time to help student achieve their academic goals.

\section{Conclusion and Implications}

Several researchers have already investigated teachers' job satisfaction and its relationship with different elements similar to performance, or students' achievements (Bernaus \& Wilson, 2008; Caprara, 2006; Corina \& Valerica, 2012). However, one of the still uncharted areas in Iran is teachers' job satisfaction and their attitude toward students' beliefs and motivation. To gain better understanding of the nature of such a relationship, three research questions were posed and appropriate research methods were utilized to collect the needed data. The quantitative findings of the study clearly indicated that there are empirically positive significant relationships $(\mathrm{t}>$ 2.56, $\mathrm{P}<0.001)$ between teachers' job satisfaction and students' motivation and beliefs. Explicitly, it showed there is both positive and significant relationship between teachers' job satisfaction and their attitudes towards students' motivation. Equally, there is a positive significant relationship between teachers' job satisfaction and their attitudes towards their students' beliefs.

Furthermore, the findings of the interviews verified the results of the questionnaire. Teachers participated in the interviews enlightened that they think their learners are enough motivated while it depends on their both level and goals to learn English. They clarified that getting confused is not because learners think that English is difficult, but it is because of lack of knowledge or some psychological problems like shyness. Moreover, concerning job satisfaction the intervieweeswere not satisfied at all. However, on the subject of helping students with their needs, making them happy, making them grow, the teachers all feel satisfied. In addition, teachers mentioned that they are friend with their students and all of them mentioned the importance of such a relationship and its impact on their learners' motivation and beliefs.

In general, the findings of the study were in line with previous studies (Brown \& McGannon, 1998; Kennedy, 1996; Toshiko, 2010; Veldman, 2005). Particularly, close to Nguni et al.'s (2006) finding, satisfied teachers showed a lot of excitement and interest about giving more energy and time to help student achieve their academic goal. The finding of this study could extents our knowledge about teachers' job satisfaction. In fact, findings of the study can be important and helpful for designing professional development programs in order to not only enhance skills and knowledge but also boost the confidence teachers at their career and as a result improve condition for learning English as a foreign language. Furthermore, it is important for educational institution to improve teachers' perception of their job through improving job environment and condition or payments and to manage language learning institutes or schools better than before

In conclusion, to bear in mind the importance of teachers' role in students achievements, teachers and authorities must become more familiar with their level of job satisfaction and its influence on their attitudes toward learners' motivation and beliefs. Although they do not have total control, teachers can affect their learners. So it 
seemsconducting more studies are needed to make the issue more clear.

\section{References}

Ajzen, I. (1988). Attitudes, personality, and behaviour. Chicago: Dorsey Press.

Alzaida, A. M. (2008). Secondary school head teachers' job satisfaction in Saudi Arabia: The results of a mixed methods approach. Annual Review of Education, Communication, and Language Sciences, 5, 161-185.

Aristovnik, A., \& Jaklič, K. (2013). Job satisfaction of older workers as a factor of promoting labour market participation in the EU: The case of Slovenia. Rev.soc.polit., 20, 2123-2148. http://www.rsp.hr/ojs2/ index.php/rsp/article/viewFile/1126/1227

Ashton, P. T., \& Webb, R. B. (1986). Making a difference: Teachers' sense of efficacy and student achievement. New York: Longman.

Beijaard, D., Verloop, N., \& Vermunt, J. D. (1999). Teachers' perceptions of professional identity: An exploratory study from a personal knowledge perspective. Teaching and Teacher Education, 16, 749-764.

Benson, S. G., \& Dundis, S. P. (2003). Understanding and motivating health care employees: Integrating Maslow's hierarchy of needs, training and technology. Journal of Nursing Management, 11, 315-320.

Bernuus, M., Wilson, A., \& Gardner, R. C. (2009). Teachers' motivation, classroom strategy use, students' motivation and second language achievement. AmlainnugeulaVruemz, 12, 25-36.

Bishay, A. (1996). Teacher Motivation and Job Satisfaction: A Study Employing the Experience Sampling Method. Journal of Undergraduate Sciences, 3, 147-154.

Burke, R. J., Greenglass, E. R., \& Schwarzer, R. (1996). Predicting teacher burnout over time: Effects of work stress, social support, and self-doubts on burnout and its consequence. Anxiety, Stress, and Coping, 9(3), 261-275.

Byrne, B. M. (1994). Burnout: Testing for the validity, replication, and invariance of causal structure across elementary, intermediate, and secondary teachers. American Educational Research Journal, 31(3), 645-673.

Chang, M. (2009). An appraisal perspective of teacher burnout: Examining the emotional work of teachers. Educational Psychology Review, 21(3), 193-218.

Cockburn, A. D., \& Haydn, T. (2004). Recruiting and retaining teachers: Understanding why teachers teach. London, England: RoutledgeFalmer.

Corina, C. C., \& Valerica, A. (2012). Teachers' perceptions and attitudes towards professional activity. Procedia -Social and Behavioral Sciences, 51, 167-171.

Coşkuner, M. (2001). Turkish Provincial State University Teachers' Perceptions of English Language Teaching as a Career (Master's thesis). Retrieved from http://www.thesis.bilkent.edu.tr/0001847.pdf

Cranny, C. J., Smith, P. C., \& Stone, E. F. (1992). Job satisfaction: How people feel about their jobs and how it affects their performance. New York, NY: Lexington Press.

Csíkszentmihályi, M. (1997). Intrinsic motivation and effective teaching: A flow analysis. In J. L. Bess (Ed.), Teaching well and liking it: Motivating faculty to teach effectively (pp. 72-98). Johns Hopkins University Press: Baltimore.

Currall, S. C., Towler, A. J., Judge, T., \& Kohn, L. (2005). Pay satisfaction and organizational outcomes. Personnel Psychology, 58, 613-640.

Davis, J., \& Wilson, S. M. (2000). Principals' effort to empower teachers: Effects on teacher motivation and job satisfaction and stress. The Clearing House, 73(6), 349-353.

Deci, E. L., \& Ryan, R. M. (1985). Intrinsic motivation and self-determination in human behaviour. New York: Plenum.

Dornyei, Z. (1994). Motivation and Motivating in the Foreign Language Classroom. The Modern Language Journal, 78, 273-284.

Dornyei, Z. (2001a). Motivational Strategies in the Language Classroom. Cambridge: Cambridge University Press.

Dörnyei, Z. (2009). Individual differences: Interplay of learner characteristics and learning environment. Language Learning, 59, 230-248. 
Dörynei, Z. (2001b). Teaching and researching motivation. Essex, England: Pearson Education Limited. Edward Arnold, London.

Doyle, T., \& Kim, M. Y. (1999). Teacher motivation and satisfaction in the United States and Korea. MEXTESOL Journal, 23(2), 35-48.

Drake, C. (2002). Experience counts: Career stage and teachers' responses to mathematics education reform. Educational Policy, 16, 311-337.

Eggen, P., \& Kauchak, D. (2002). Strategies for teachers: Teaching content and thinking skills (4th ed.). Needham Heights: M.A. 15.

Evans, L. (2001). Delving deeper into morale, job satisfaction, and motivationamongeducation professionals. Educational Management and Administration, 29, 291-306.

Fenfang, L. (2010). Relationship between EFL Learners' Belief and Learning Strategy Use by English Majors in Vocational Colleges. Journal of Language Teaching and Research, 1(6), 858-866. http://dx.doi.org/10.4304/j1tr.1.6.858-866

Fishbein, M., \& Ajzen, I. (1975). Belief, attitude, intention, and behaviour: An introduction to theory and research. Reading, MA: Addison-Wesley.

Fried, Y., \& Ferris, G. (1986). The validity of the job characteristics model: A review and meta-analysis. Personnel Psychology, 40(2), 287-322.

Friedman, I. A. (1995). Student behavior patterns contributing to teacher burnout. Journal of Educational Research, 88(5), 281-289.

Gardner, R. (1985). Social Psychology and Second Language Learning: The Role of Attitude.

Gardner, R., \& Lambert, W. (1959). Motivational variables in second language acquisition. Canadian Journal of Psychology, 13, 266-272.

Gardner, R., Masgoret, A.-M., Tennant, J., \& Mihic, L. (2004). Integrative motivation: Changes during a year-long intermediate-level language course. Language Learning, 54(1), 1-34.

Garner, H. (1995). Teamwork models and experience in education. Needham Heights, MA: Allyn and Bacon.

Gay, L. R., Mills, G. E., \& Airasian, P. (2006). Educational research: Competencies for analysis and applications (8th ed.). Upper Saddle River, NJ: Merrill.

Goodlad, J. (1990). Teacher for our nation's schools. San Francisco, CA: Jossey-Bass.

Gritzmacher, J. B., \& Smith, B. P. (1998). Job Satisfaction of Family and Consumer Sciences Teacher: Implication for Teacher Shortage, Teacher Education and In-Service Education. Journal of Family and Consumer Sciences Education, 16(2), 85. Retrieved from http://www.natefacs.org/Pages/v16no2/16-2-85\% 20Smith.pdf

Griva, E., Panitsidou, E., \& Chostelidou, D. (2012). Identifying factors of job motivation and satisfaction of foreign language teachers: research project design. Procedia-Social and Behavioral Sciences, 46, 543-547.

Hackman, J. R., \& Oldham, G. R. (1980). Work redesign. Reading, MA: Addison-Wesley.

Heidari-Soureshjani, K. S., \& Naseri, N. (2011). The Interrelationship of Instrumental, Integrative, Intrinsic, and Extrinsic Motivations and the Lexical-oriented Knowledge among Persian EFL Language Learners. Theory and Practice in Language Studies, 1(6), 662-670. http://dx.doi.org/10.4304/tpls.1.6.662-670

Herrick, H. S. (1973). The Relationship of Organizational structure to Teacher Motivation in Multiunit and Non-Multiunit Elementary Schools. ERIC_NO: 101442(available through Intralibrary loan only).

Herzberg, F. A., Mausner, B., \& Sherwitz, L. (1959). The Motivation to Work. NewYork: John Wiley \& Sons Inc.

Hong Goo, K. (2011). Job Satisfaction among Korean Academics: A Critical Investigation (Doctoral dissertation, University of Nottingham.). Retrieved from http://eprints.nottingham.ac.uk/id/eprint/12976

Hong, K. (2006). Beliefs about Language Learning and Language Learning Strategy Use in an EFL Context: A Comparison Study of Monolingual Korean and Bilingual Korean-Chinese University Students (Doctoral dissertation, Denton, Texas. UNT Digital Library). Retrieved from http://www.natefacs.org/Pages/v16no2/ 16-2-85\%20Smith.pdf 
Horwitz, E. K. (1987). Surveying student beliefs about language teaming. In A. L. Wenden, \& J. Robin (Eds.), Learner strategies in language learning (pp. 119-132). London: Prentice Hall.

Hughes, V. M. (2006). Teacher Evaluation Practices and Teacher Job Satisfaction (Doctoral dissertation, The Faculty of the Graduate School University of Missouri-Columbia). Retrieved from http://hdl.handle.net/10355/4468

Imani Nojani, M., Arjmandnia, A. A., Afrooz, G. A., \& Rajabi, M. (2012). The study on relationship between organizational justice and job satisfaction in teachers working in general, special and gifted education systems. Procedia-Social and Behavioral Sciences, 46, 2900-2905.

Ingersoll, R. M. (2003). Is there really a teacher shortage? The Center for the Study of Teaching and Policy and the Consortium for Policy Research in Education. Retrieved August 15, 2008, from http://depts.washington.edu/ctpmail/PDFs/Shortage-RI-09-2003.pdf

Ispir, O. A. (2010). Teachers' Burnout Levels and Their Attitudes towards Teaching Profession. EABR \& ETLC Conference Proceedings (pp. 229-233). Dublin, Ireland.

Kalleberg, A. L. (1977). Work values and job rewards-Theory of job satisfaction. American Sociological Review, 42, 124-143.

Kern, R. G. (1995). Students' and Teachers' Beliefs about Language Learning. Foreign Language Annals, 28 , 71-92. http://dx.doi.org/10.1111/j.1944-9720.1995.tb00770.x

Klassen, R. M., \& Ming Ming, C. (2010). Effects on Teachers' Self-Efficacy and Job Satisfaction: Teacher Gender, Years of Experience, and Job Stress. Journal of Educational Psychology, 102(3), 741-756. http://dx.doi.org/10.1037/a0019237

Kormos, J., Kiddle, T., \& Csizér, K. (2011). Goals, attitudes and self-related beliefs in second language learning motivation: An interactive model of language learning motivation. Applied Lingustics, 32(5), 495.

Kozkoski, W. (2002). Motivation to teach English: A study of EFL instructors in Japan (Unpublished paper presented at The 4th Temple University Japan Applied Linguistics Colloquium). 16.

Landy, F. J. (1989). Psychology of work behavior. Pacific Grove. CA: Brooks/Cole.

LaRocco, J. M., House, J. S., \& French, J. R. P. Jr. (1980). Social support, occupational stress, and health. Journal of Health and Social Behavior, 2, 202-218.

LeCompte, M. D., \& Dworkin, A. G. (1991). Giving up on school: Student dropouts and teacher burnouts. Newbury Park, CA: Corwin.

Lester, P. E. (1987). Development and factor analysis of the Teacher Job Satisfaction Questionnaire. Educational and Psychological Measurement, 47(1), 223-233.

Lightbrown, P. M., \& Spada, N. (2006). How Languages are Learned (3rd ed.). Oxford: Oxford University Press.

Lipsitz, J. (1984). Successful school for young adolescents. New Brunswick, NJ: Transaction Books.

Locke, E. A. (1976). The nature and causes of job satisfaction. In M. C. Dunnette (Ed.), Handbook of industrial and organizational psychology (pp. 1297-1349). Chicago, IL:Rand McNally.

Maslow, A. H. (1954). Motivation and personality. New York, NY: Harper.

Merdassa, A. B. (2012). Assessment of the Attitude of Prospective Teachers Enrolled in Postgraduate Diploma in Teaching: The Case of Wollega University. Science, Technology and Art Research Journal, 1(4), 65-73. Retrieved from http://www.ajol.info/index.php/star/article/view/98827

Mills, N., Pajares, F., \& Herron, C. (2007). Self-efficacy of college intermediate French students: Relation to achievement and motivation. Language Learning, 57, 417-442.

Miskel, C., McDonald, D., \& Bloom, S. (1983). Structural and expectancy linkages within schools and organizational effectiveness. Educational Administration Quarterly, 19, 49-82.

Moore, B. M. (1987). Individual difference and satisfaction with teaching. Paper presented at the annual meeting of the American Educational Research Association. Washington, D. C. (ERIC Document Reproduction Service No. ED282851)

Moorman, R. H. (1993). The influence of cognitive and affective based job satisfaction measures on the relationship between satisfaction and organizational citizenship behavior. Human Relations, 6, 759-776. 
Nguni, S., Sleegers, P., \& Denessen, E. (2006). Transformational and transactional leadership effects on teachers' job satisfaction, organizational commitment, and organizational citizenship behavior in primary schools: The Tanzanian case. School Effectiveness and School Improvement, 17, 145-177.

Ormrod, J. E. (2008). Educational psychology: Developing learners (6th ed.). New York: Pearson/Prentice Hall.

Oxford, R. L., \& Shearin, J. (1994). Language learning motivation: Expanding the theoretical frame work. Modern Language Journal, 78, 12-28.

Papastamatis, A., Panitsidou, E., Giavrimis P., \& Papanis, E. (2009). Facilitating Teachers' and Educators' Effective Professional Development. Review of European Studies, 1(2), 83-90.

Pearson, L., \& Moomaw, W. (2005). The relationship between teacher autonomy and 119 stress, work satisfaction, empowerment, and professionalism. Education Research Quarterly, 29(1), 37-53.

Pinder, C. C. (1984). Work Motivation: Theory, Issues and Application. Dallas and Schoh, Foresman.

Pintrich, P. R., \& De Groot, E. V. (1990). Motivational and self-regulated learning components of classroom academic performance. Journal of Educational Psychology, 82(1), 33-40.

Pintrich, P. R., \& Schunk, D. H. (2002). Motivation in Education: Theory, Research, and Application (2nd ed.). Upper Saddle River, NJ: Prentice Hall.

Quaglia, R., \& Marion, S. (1991). The relationship of teacher satisfaction to perceptions of school organization, teacher empowerment, work conditions, and community status. Education, 112(2), 206-222.

Rain, J. S., Lane, I. M., \& Steiner, D. D. (1991). A current look at the job satisfaction/life satisfaction relationship: Review and future considerations. Human Relations, 44, 287-307.

Roeser, R., Arbreton, A., \& Anderman, E. (1993). Teacher characteristics and their effects on student motivation across the school year. Paper presented at the annual meeting of the American Educational Research Association, Atlanta 17.

Roethlisberger, F. J., \& Dickson, W. J. (1939). Management and the worker. Cambridge. MA: Harvard University Press.

Ryan, R. M., \& Deci, E. L. (2000). Self-determination theory and the facilitation of intrinsic motivation, socialdevelopment, and well-being. American Psychologist, 55, 68-78.

Scheidecker, D., \& Freeman, W. (1999). Bringing out the best in students: How legendary teachers motivate kids. London: SAGE.

Schumann, F. M. (1980). Diary of a Language Learner: A Further Analysis, 51-57. In R. C. Scarcella, \& S. D. Krashen (Eds.), Research in Second Language Acquisition: Selected Papers of the Los Angeles Second Language Acquisition Research Forum. Rowley, MA: Newbury House.

Schumann, F. M., \& Schumann, J. H. (1977). Diary of a Language Learner: An Introspective Study of Second Language Learning. In H. D. Brown, R. H. Crymes, \& C. A. Yorio (Eds.), on TESOL '77: Teaching and learning English as a second language-Trends in research and practice (pp. 241-249). Washington DC: TESOL.

Sergiovanni, T. J. (1969). Factors that affect satisfaction and dissatisfaction of teachers. In F. D. Carver, \& T. J. Sergiovanni (Eds.), Organization and humanbehavior (pp. 249-260). New York: McGraw Hill.

Smith, P. C., Kendall, L. M., \& Hulin, C. L. (1969). The measurement of satisfaction in work and retirement. Chicago: Rand McNally.

Spector, P. E. (1997). Job satisfaction: Application, assessment, causes and consequences. Thousand Oaks, CA: SAGE.

Spuk, D. W. (1974). Reward structures in the Public High schools. Educational Administration Quarterly, 10(1), 18-34.

Stevick, E. W. (1980). Teaching Languages: A Way and Ways. Rowley, Mass: Newbury House.

Thompson, E. R., \& Phua, F. T. T. (2012). A brief index of affective job satisfaction. Group \& Organization Management, 37(3), 275-307.

Thomson, S. (1979). Motivation of Teachers. ERIC_NO: ED178998 (available through Intralibrary loan only).

Thoonen, E. E. J., Sleegers, P. J. C., Peetsma, T. T. D., \& Oort, F. J. (2010). Can teachers motivate students to learn? 73(3), 345-360. http://dx.doi.org/10.1080/03055698.2010.50700 
Tziava, K. (2003). Factors that motivate and demotivate Greek EFL teachers (Doctoral dissertation, The University of Edinburgh, Moray House School of Education). Retrieved from http://hdl.handle.net/1842/495

Ushioda, E. (2003). Motivation as a socially mediated process. In D. Little, J. Ridley, \& E. Ushioda (Eds.), Learner autonomy in the foreign language classroom: Teacher, learner, curriculum and assessment (pp. 90-102). Dublin: Authentic.

Weiss, H. M. (2002). Deconstructing job satisfaction setting evaluations, beliefs, and affective experiences. Human Resource Management Review, 12(2), 173-194.

Wesely, M. (2012). Learner Attitudes, Perceptions, and Beliefs in Language Learning. Foreign Language Annals, 45(S1), S98-S117.

\section{Copyrights}

Copyright for this article is retained by the author(s), with first publication rights granted to the journal.

This is an open-access article distributed under the terms and conditions of the Creative Commons Attribution license (http://creativecommons.org/licenses/by/3.0/). 